\title{
LATIHAN FISIK DAN KEKEBALAN TUBUH
}

Oleh: Hari Yuliarto

Dosen Jurusan Pendidikan Olahraga dan Rekreasi FIK UNY

Abstrak

Kekebalan tubuh adalah kemampuan untuk melawan segala macam organisme atau toksin yang cenderung merusak jaringan dan organ tubuh. Perlawanan terhadap penyakit tergantung pada kualitas kekebalan tubuh seseorang, jika memiliki kekebalan tubuh yang baik akan terhindar dari penyakit, sementara yang kekebalan tubuhnya lemah akan mudah terserang penyakit.

Latihan fisik yang benar, teratur, berbeban individual dan menyenangkan dapat memperbaiki dan menghambat penurunan fungsi organ tubuh, menyehatkan tubuh serta meningkatkan daya tahan tubuh terhadap penyakit infeksi. Latihan fisik ringan sekalipun, seperti aerobik selama 30 menit, mampu mengaktifkan kerja sel darah putih, yang merupakan komponen utama kekebalan tubuh pada sirkulasi darah. Seseorang yang berolahraga secara teratur lebih sedikit kemungkinan untuk jatuh sakit dibandingkan yang samasekali tidak berolahraga. Namun, berolahraga yang berlebihan, atau terlalu sering, malah bisa mengurangi kekebalan tubuh.

Kata Kunci: Latihan, kekebalan tubuh

Salah satu yang bisa menangkal serangan penyakit pada tubuh kita adalah sistem kekebalan tubuh. Dengan

MEDIKORA Vol. IV, No 1, April 2008: 47-65 
meningkatkan ketahanan tubuh dan mempertahankannya maka badanpun akan terhindar dari penyakit yang menyeràng. Apabila kondisi kekebalan tubuh sedang menurun, maka penyakitpun akan mudah menyerang tanpa banyak perlawanan dari sistem kekebalan tubuh.

Cara yang paling sederhana untuk meningkatkan kekebalan tubuh adalah dengan melakukan latihan fisik/ olahraga serta istirahat dan tidur yang cukup. Latihan fisik ringan sekalipun, seperti aerobik selama 30 menit, mampu mengaktifkan kerja sel darah putih, yang merupakan komponen utama kekebalan tubuh pada sirkulasi darah. Idealnya melakukan latihan aerobik selama 30 menit, lima kali seminggu. Tetapi, jangan melakukan olahraga berlebihan, karena justru akan mengakibatkan tertekannya kekebalan tubuh. Contohnya adalah banyak pelari maraton yang menderita pilek dan flu sesudah bertanding. Tentunya, istilah berlebihan ini tergantung pada tingkat ketahanan serta ketahanan tubuh seseorang. Sebelum melakukan latihan olahraga, dianjurkan untuk berkonsultasi dengan dokter atau pelatih, terutama untuk para pemula. (http://cybermed.cbn.net.id/cbprti/cybermed/detail.aspx) 


\section{Lekosit (Sel darah putih)}

Lekosit merupakan unit mobil/aktif dari sistem pertahanan tubuh. Sistem pertahanan tubuh ini dibentuk di dalam sumsum tulang (granulosit dan mososit, dan sedikit limfosit) dan sebagian lagi di dalam jaringan limfe (eritrosit dan sel-sel plasma), tetapi setelah dibentuk sel-sel ini akan diangkut di dalam darah menuju ke berbagai macam bagian tubuh untuk dipergunakan. Manfaat sel-sel lekosit ini adalah kebanyakan sel-sel ini secara khusus dibawa atau diangkut menuju daerah-daerah yang mengalami peradangan yang berat, jadi sel-sel ini menyediakan pertahanan yang cepat dan kuat terhadap agen infeksi yang mungkin ada (Guyton dan Hall, 1996: 445).

Pada keadaan normal terdapat 4.000-11.000 sel lekosit per mikro liter darah manusia. Dari jumlah itu, jenis terbanyak adalah granulosit (lekosit polimorfonuklear, pmn). Sebagian besar sel tersebut mengandung granulanetrofilik), sebagian kecil mengandung granula yang dapat diwarnai dengan zat warna asam (eosinofil), dan sebagian lagi mengandung granula basofilik (basofil). Dua jenis sel lain yang lazim ditemukan dalam darah tepi adalah limfosit, yang memiliki inti bulat besar dan sitoplasma sedikit, serta monosit, yang mengandung banyak granula sitoplasma tidak 
bergranula dan mempunyai inti berbentuk menyerupai ginjal. Kerja sama sel-sel tersebut menyebabkan tubuh memiliki sistem pertahanan yang kuat terhadap berbagai tumor dan infeksi virus, bakteri serta parasit (Ganong, 1999: 338). Walaupun ada beberapa tipe dari lekosit dan berbeda bentuknya secara morfologis semua bagian berfungsi bersama yaitu membantu mempertahankan tubuh melawan masuknya mikroba asing (Kapit dkk, 1987: 139).

Nilai Normal Berbagai Komponen Sel dalam Darah Manusia

\begin{tabular}{|l|c|l|l|}
\hline Sel & Se $/ \mu \mathrm{L}$ & $\begin{array}{l}\text { Kisaran Nilai } \\
\text { Normal }\end{array}$ & $\begin{array}{l}\text { Persen } \\
\text { Darah } \\
\text { Total }\end{array}$ \\
\hline $\begin{array}{l}\text { Sel Darah } \\
\text { Putih Total }\end{array}$ \\
\hline $\begin{array}{l}\text { Granulosit } \\
\text { Netrofil }\end{array}$ & 5000 & $4000-11000$ & \\
\hline Eosinofil & 275 & $3000-6000$ & $50-70$ \\
\hline Basofil & 35 & $0-100$ & 0,4 \\
\hline Limfosit & 2750 & $1500-4000$ & $20-40$ \\
\hline Monosit & 540 & & $2-8$ \\
\hline Eritrosit & & & \\
\hline Wanita & $4,8 \times 10^{6}$ & & \\
\hline Pria & $5,4 \times 10^{6}$ & & \\
\hline Trombosit & 300.000 & $200.000-$ & \\
\hline
\end{tabular}

Sumber : (Ganong, 1999) 


\section{KEKEBALAN TUBUH}

Menurut Guyton dan Hall (1996:435) tubuh manusia mempunyai kemampuan untuk melawan segala macam organisme atau toksin yang cenderung merusak jaringan dan organ tubuh. Kemampuan itu disebut kekebalan atau imunitas. Sebagian besar imunitas disebabkan oleh suatu imun khusus yang membentuk antibodi dan limfosit yang diaktifkan yang akan menyerang dan menghancurkan toksin tertentu, kekebalan ini disebut kekebalan buatan/kekebalan yang didapat/sistem imun spesifik (acquired adaptive immunity) Ada suatu jenis imunitas tambahan yang disebabkan oleh proses umum dan bukan disebabkan dari proses untuk melawan organisme penyebab penyakit spesifik. Kekebalan ini disebut kekebalan bawaan/sistem imun nonspesifik (innate immunity).

Sistem imun buatan ini mempunyai kemampuan untuk mengenal benda yang dianggap asing bagi dirinya. Benda asing yang pertama kali muncul segera dikenal sehingga terjadi sensitisasi sel-sel sistem imun tersebut. Bila sel imun tersebut berpapasan kembali dengan sel asing yang sama, maka benda asing yang terakhir ini akan dikenal lebih cepat kemudian akan dihancurkan (Baratawidjaya, 1991: 30).

MEDIKORA Vol. IV, No 1, April 2008: 47-65 
Respon imun menurut pendapat modern menjalankan tiga fungsi utama yaitu pertahanan (defense), homeostatis dan pengawasan (survaillance) (Bellanti, 1985: 15)' Kondisi stress berhubungan erat dengan respon imun. Pada saat stress, terjadi respon imun yang lebih bertujuan untuk mengembalikan keadaan individu pada keadaan homeostatis (Locke, 1982 dalam Miller dan Norin, 1989).

\section{Komponen Sel Kekebalan Tubuh}

Sel-sel darah yang terlibat dalam respon imun diturunkan dari pluripoten hematopoitik stem cell (Sigal dan Ron, 1994 dalam Damayanti, 1999: 8). Stem cell tersebut kemudian berdeferensiasi menjadi dua jalur yang berlainan, yaitu: mieloid dan limfoid. Mieloid terdiri dari granulosit polimorfonuklear (basofil/ mass cell, netrofil, eosinofil), monosit/ makrofag dan megakariosit/ platelet, sedangkan limfoid terdiri dari limfosit T, limfosit B, dan sel NK (Norin, 1989: 15). Limfosit, netrofil, eosinofil, basofil dan monosit merupakan unit yang aktif pada sistem imunitas, sehingga diberi nama sel imunokompeten. Sel-sel imunokompeten tersebut dapat digunakan sebagai indikator kualitas ketahanan/kekebalan tubuh. Indikator kekebalan tubuh yang innate akan diwakili oleh basofil, eosinofil, netrofil, dan monosit, sedangkan indikator kekebalan tubuh yang adaptive 
diwakili oleh limfosit (Kuby, 1992; Roitt dkk,1996). Kebanyakan dari sel-sel ini di dalam aliran darah bersifat non fungsional dah bilamana secara khusus diangkut menuju ke jaringan yang mengalami peradangan (Ganong, 1999:331).

\section{a. Granulosit polimorfonuklear}

Semua sel granulosit memiliki granula sitoplasmik yang mengandung substansi biologik aktif, yang berperan dalam reaksi peradangan dan alergi (Ganong, 1999: 340). Polimorfonuklear (PMN) granulosit berdasarkan pengecatan granula dalam sitiplasmanya, dibedakan dalam tiga macam sel, yaitu netrofil, basofil dan eosinofil. PMN didalam sirkulasi darah berjumlah 60-70\%, sedangkan sisanya mengalami ekstravasasi. PMN mempunyai umur singkat, kira-kira hanya 2 sampai 3 hari. Sel-sel ini berperan penting dalam reaksi inflamasi. Sel-sel ini (terutama netrofil) akan memfagositosis dan merusak organisma yang diselubungi antibodi dan komplemen. Eosinofil, basofil, dan sel mast dapat melepskan enzim ke ekstraseluler melalui fusi dari granula intraseluler spesifik di plasma membran, melalui proses eksositosis (Norin, 1989: 18).

\section{b. Eosinofil}

Jumlah eosinofil kira-kira 2-5\% dari sel darah putih pada keadaan normal (Roitt, et al, 1996). Eosinofil dibedakan

MEDI KORA Vol. IV, No 1, April 2008: 47-65 
dari sel yang lain karena mempunyai granula berwarna merah jingga yang berisi protein basa dan enzim perusak. Seperti halnya netrofil, eosinofil juga dapat melakukan fagositas dan membunuh mikroorganisma. Kalau mendapat rangsangan yang sesuai, eosinofil menjadi aktif dan terjadilah degranulasi. Akibatnya adalah dilepaskannya berbagai enzim yang dapat menghancurkan berbagai mediator yang dilepaskan oleh basofil dan mastosit (Kresno, 1996: 20).

Eosinofil sangat aktif dalam pertahanan infeksi parasit dan memainkan peranan kecil dalam asma (Mackinon, 1992: 35). Sedangkan menurut Peakman dan Vergoni (1997: 30) , peran utama eosinofil pada pertahanan host adalah proteksi melawan parasit multi seluler seperti cacing (helmints) yang dihasilkan oleh pelepasan toksin protein kation.

\section{MEKANISME KERJA SISTEM IMUNITAS}

Perlawanan terhadap penyakit tergantung pada kualitas kekebalan tubuh seseorang, jika memiliki kekebalan tubuh yang baik akan terhindar dari penyakit, sementara yang kekebalan tubuhnya lemah akan mudah terserang penyakit. Pada tahun 1981 sejumlah penderita pneumonia di usia muda tidak terselamatkan walaupun sudah dirawat di rumah sakit dengan menggunakan jenis antibiotika terbaru yang canggih. 
Padahal, umumnya penyakit ini dapat diobati hanya dengan antibiotik sederhana. Para dokter tercengang pada saat mendapati fenomena bahwa kekebalan tubuh para pasien muda tersebut telah lumpuh akibat terserang virus HIV. Munculnya virus HIV dan AIDS itu menyadarkan dunia kesehatan akan pentingnya kekebalan tubuh dalam melawan penyakit.

http://www.infobunda.com/pages/articles/artikelshow.php? $\underline{\mathrm{id}=27}$ )

Kinerja sistem imunitas bekerja secara menyeluruh dalam menjaga keberadaan organ biologis dari serbuan penyakit dari luar tubuh. Sesekali, barulah sistem tersebut mengisyaratkan 'tanda bahaya' kondisi tubuh menurun, yaitu dengan munculnya rasa sakit. Tugas dasar sistem imunitas tersebut antara lain adalah membedakan 'dirinya sendiri' (seluruh sel di dalam tubuh) dengan pendatang asing' (bakteri, virus, toksik, jamur, serta jaringan asing). Menghadapi serbuan asing tadi, sistem imunitas harus membentuk sel khusus melalui sel darah putih, untuk mengeliminasi pendatang asing tersebut. http://www.infobunda.com/pages/articles/artikelshow.php? $\underline{\mathrm{id}=27}$

MEDI KORA Vol. IV, No 1, April 2008: 47-65 
Manusia sebagai mahluk sosial yang berinteraksi dengan lingkungan sekitar, sistem imunitas juga mampu beradaptasi dengan kondisi lingkungan. Oleh karenanya, masyarakat kita yang lingkungan hidupnya tidak terlalu bersih, tidak banyak mengalami gangguan kesehatan, meski sering mengkonsumsi jajanan yang kurang higienis. Sementara, masyarakat di negeri-negeri Barat yang terbiasa berada di lingkungan yang serba bersih, dengan mudah terserang diare bila mengkonsumsi makanan yang kurang higienis.

Kekebalan tubuh bekerja seperti polisi. Saat kita diam, mereka tinggal di posnya, di jaringan limpa. Dalam hitungan menit jika seseorang memulai berolahraga, dan beberapa jam sesudahnya, mereka meninggalkan posnya dan berpatroli dalam tubuh. Efek dari patroli ini sangat kuat. Saat mensurvei 150 orang yang rajin melakukan latihan fisik/ olahraga jalan selama 12 minggu, jarang ada yang terkena flu dan radang tenggorokan dibanding yang tidak berolahraga. Untuk memerangi infeksi, 30-60 menit berolahraga yang cukup adalah yang terbaik. Olahraga lebih dari 90 menit, ternyata memangkas sistem kekebalan tubuh seseorang (http://indonesiaindonesia,com/f/19039-hubungan-

olahraga-and-sistem-kekebalan) 


\section{Lekosit dan Latihan}

Sirkulasi dari jumlah lekosit mungkin meningkat terus menerus setelah sesi latihan, dan mungkin tetap meningkat untuk periode yang lama (sampai 24 jam) setelah beberapa tipe latihan. Secara umum, besarnya lekositosis nampak berhubungan langsung dengan intensitas latihan dan durasi, dan berbanding terbalik dengan tingkat kebugaran; durasi latihan mungkin faktor yang sangat penting. Peningkatan jumlah lekosit lebih utama pada peningkatan netrofil dan lebih luas lagi jumlah limfosit walaupun jumlah monosit juga meningkat (Mackinon, 1992: 50).

Atlet yang terlatih baik menunjukkan jumlah lekosit istirahat rendah, sebagai contoh, Green dkk, melaporkan bahwa 4 dari 20 pelari mempunyai jumlah lekosit rendah $(4,3$ x $10^{3}$ per $\mu \mathrm{L}$ : normalnya adalah berkisar $4-11 \times 10^{3}$ per $\left.\mu \mathrm{L}\right)$. Demikian pula dengan jumlah lekosit kurang dari $5 \times 10^{3}$ per $\mu \mathrm{L}$ telah dilaporkan pada 5 dari 9 pelari jarak jauh (Moorthy dan Zimmerman, 1978: 274).

Peningkatan jumlah lekosit mengikuti macam-macam latihan, lama durasi dari beberapa detik sampai beberapa jam (marathon dan berbaris). Besarnya peningkatan bervariasi dan ditentukan oleh kombinasi intensitas latihan dan durasi.

MEDIKORA Vol. IV, No 1, April 2008: 47-65 
Sebagai contoh, peningkatan sampai dua kali setelah lebih dari satu jam latihan, 2-3 kali jam latihan dan 4 kali setelah lebih dâri 2 jam latihan (McCarthy dan Dale, 1988: 340).

\section{Granulosit dan Latihan}

Jumlah granulosit meningkat secara menyolok setelah latihan berat atau latihan panjang tetapi mungkin tidak berubah setelah latihan ringan atau latihan dengan intensitas rendah. Peningkatan yang besar setelah latihan panjang, sebagi contoh jumlah granulosit tidak berubah setelah berjalan naik pada 50\% VO2 max, meningkat lebih dari 300\% setelah maraton, terus meningkat $26 \%$ setelah 10 menit memanjat tangga (Moorthy dan Zimmerman, 1978: 276). Jumlah granulosit mungkin tetap meningkat untuk beberapa jam setelah latihan lama yang intensif (Nieman, Berg dkk. 1989: 320).

Sebaliknya jumlah lekosit dan netrofil secara berangsur-angsur menurun ke tingkat dasar setelah latihan. Jumlah limfosit mungkin menurun di bawah tingkat istirahat sebelum kembali normal setelah latihan daya tahan, contohnya pada pelari maraton telah menurun 20\% 1,5 jam setelah 3 jam berlari dibanding pada tingkat preexercise. Jumlah limfosir kembali normal 6 jam, walaupun jumlah 
lekosit dan granulosit tetap tinggi pada waktu ini (Nieman, Berg dkk. 1989: 320).

Sirkulasi jumlah lekosit meningkat secara nyata selama latihan dan besarnya meningkat berhubungan dengan intensitas dan durasi latihan. Peningkatan jumlah lekosit terutama pada jumlah granulosit. Latihan juga meningkatkan sirkulasi jumlah limfosit dan menyebabkan perubahan pada proporsi yang relatif pada sel $\mathrm{T}$, sel $\mathrm{B}$ dan sel NK serta pada subset sel T (CD4 dan CD8). Setelah latihan jumlah lekosit total dan granulosit tetap meningkat selama beberapa jam, sedangkan jumlah limfosit menurun di bawah garis dasar sebelumkembali ke nilai preexercise. Perubahan angka pada jumlah lekosit dan limfosit selama latihan tidak lama dan kembali normal dalam 24 jam.Perubahan ini hanya menggambarkan redistribusi keberadaan sel antar perbedaan bagian limfosit dan tidak mengidentifikasikan sintesa dari sel baru (Mackinon,1996).

Penelitian Gabriel dkk. (1992) pada 11 atlet sehat menunjukkan ada peningkatan eosinofil pada15 menit estela latihan maksimal (60 detik) dengan sepeda ergometer, tetapi menurun di bawah nilai pre exercise 2 jam setelah latihan. Surkina dan Kozlovskoya (1980: 10) menyatakan ada penurunan jumlah eosinofil selama latihan intensif. 
Sedangkan Christensen RD dan Hill HR (1987) membuktikan ada peningkatan yang besar pada jumlah eosinofil (meningkat $139 \%$ ) pada post exercise pada anggota tim atletik SMU yang berlari naik tangga dengan langkah cepat selama 10 menit.

\section{LATIHAN FISIK DAN KEKEBALAN TUBUH}

Latihan fisik yang benar, teratur, berbeban individual dan menyenangkan dapat memperbaiki dan menghambat penurunan fungsi organ tubuh, menyehatkan tubuh serta meningkatkan daya tahan tubuh terhadap penyakit infeksi (Kumae, 1987: 65). Pemberian rangsang fisik yang berulang pada sistem tubuh akan menyebabkan proses adaptasi yang dapat mencerminkan peningkatan kemampuan fungsional tetapi jika besarnya rangsang tidak cukup untuk proses pembebanan, maka tubuh tidak akan terjadi proses adaptasi. Sebaliknya jika rangsang terlalu besar yang tidak dapt ditoleransi oleh tubuh akan menyebabkan jejas dan mengganggu keadaan homeostasis pada sistem tubuh (Setyawan,1995: 96)

Sehubungan dengan pengaruh latihan terhadap konsentrasi darah putih sebagai parameter deteksi peningkatan sistem imán dalam tubuh, Nieman (1994) menyatakan bahwa latihan fisik tingkat sedang merangsang 
sistem imán, tetapi latihan fisik yang intensif dapat menyebabkan penurunan sistem imán. Tetapi masih belum jelas aspek-àspek latihan manakah yang paling merusak sistem imán dan lebih rawan/rentan terhadap infeksi. Jadi respon imun pada tubuh sebagai akibat dari latihan belum diketahui dengan jelas. Latihan yang digunakan oleh Nieman ádalah latihan treadmill selama 45 menit dengan intensitas tinggi (80\% VO2 max) dan intensitas sedang (50\% VO2 max).

Beberapa hasil penelitian belum ada kesepakatan mengenai beban dan bentuk latihan fisik yang meningkatkan atau menurunkan ketahanan tubuh. Secara umum penelitian menunjukkan bahwalatihan fisik dengan intensitas tinggi menimbulkan kerusakan respon ketahanan tubuh, sedangkan pada beban latihan fisik sedang belum ada kesepakatan kesamaan hasil penelitian (Mackinon, 1992: 53). Ketahanan tubuh dengan beban yang sama pada program latihan fisik masih memberikan gambaran respon yang berbeda (Frisina, 1993) .

Riset membuktikan bahwa perubahan-perubahan positif akan terjadi di dalam sistem kekebalan tubuh selama berolahraga secara moderat atau sedang-sedang saja. Sel-sel sistem kekebalan tubuh akan bersirkulasi dengan lebih cepat di dalam tubuh, dan kemungkinan juga ada dorongan

MEDIKORA Vol. IV, No 1, April 2008: 47-65 
sementara di dalam produksi macrophage, yakni sel-sel yang menyerang bakteri. Perubahan ini mungkin akan berakhir hanya beberapa jam setelah berolahraga, namun ada keuntungan kumulatif bagi yang berolahraga secara moderat dan teratur. Seseorang yang berolahraga secara teratur lebih sedikit kemungkinan untuk jatuh sakit dibandingkan yang samasekali tidak berolahraga. Namun, berolahraga yang berlebihan, atau terlalu sering, malah bisa mengurangi kekebalan tubuh.

http: / / analisadaily.com/index.php?option=com).

\section{Kesimpulan}

Dengan meningkatkan ketahanan tubuh dan mempertahankannya maka badanpun akan terhindar dari penyakit yang menyerang. Apabila kondisi kekebalan tubuh sedang menurun, maka penyakitpun akan mudah menyerang tanpa banyak perlawanan dari sistem kekebalan tubuh. Perlawanan terhadap penyakit tergantung pada kualitas kekebalan tubuh seseorang, jika memiliki kekebalan tubuh yang baik akan terhindar dari penyakit, sementara yang kekebalan tubuhnya lemah akan mudah terserang penyakit

Cara yang paling sederhana untuk meningkatkan kekebalan tubuh adalah dengan melakukan latihan fisik/ 
olahraga serta istirahat dan tidur yang cukup. Latihan fisik ringan sekalipun, seperti aerobik selama 30 menit, mampu mengaktifkan' kerja sel darah putih, yang merupakan komponen utama kekebalan tubuh pada sirkulasi darah. Idealnya melakukan latihan aerobik selama 30 menit, lima kali seminggu. Tetapi, jangan melakukan olahraga berlebihan, karena justru akan mengakibatkan tertekannya kekebalan tubuh. Contohnya adalah banyak pelari maraton yang menderita pilek dan flu sesudah bertanding. Tentunya, istilah berlebihan ini tergantung pada tingkat ketahanan serta ketahanan tubuh seseorang. Sebelum melakukan latihan olahraga, dianjurkan untuk berkonsultasi dengan dokter atau pelatih, terutama untuk para pemula.

\section{Daftar Pustaka}

Baratawidjaya KG. 1991. Imunologi Dasar. Edisi kedua: Jakarta, FK UI

Bellanti JA. 1985. Immunology III. Philadelphia: WB Saunders Co

Damayanti R. 1999. Pengaruh Hormon Hidrokortison dan Adrenalin terhadap Pola Respon Mobilitas Sel Imunokompeten dalam Darah Tikus Putih. Tesis. Unair Surabaya

MEDIKORA Vol. IV, No 1, April 2008: 47-65 
Frisina JP, Gauderi S, Cable T, Keast, Palmer TN. 1993. Effect of Acute Exercise on Lymphocite Sub Set and Metabolic Activity. Int. J. Sport Med., 15(1).

Guyton AC dan Hall JE. 1996. Texbook of Medical Physiology.

9 ed. Philadelphia: WB Saunders Company

Ganong WF. 1999. Review of Medical Physiology. 18 ed New Jersey: Prentice Hall

http:/ / analisadaily.com/index.php?option=com.

diambil pada 13-1-2009

http://cybermed.cbn.net.id/cbprti/cybermed/detail.aspx. diambil pada 27-11-2008

http://indonesiaindonesia,com/f/19039-hubungan-olahragaand-sistem-kekebalan. diambil pada 27-11-2009

http://www.infobunda.com/pages/articles/artikelshow.php?i $\underline{\mathrm{d}=27}$. diambil pada 13-1-2009

Kresno SB. 1996. Imunologi: Diagnosis dan Prosedur Laboratorium. Edisi ketiga. Jakarta: Balai Penerbit FKUI

Mackinon LT, 1992. Exercise and Immunology. Champaign: Human Kenetics Publisher Inc.

McCarthy dan Dale, 1988. The Leucocytosis of Exercise: A Riview and Model. Sport Medicine

Moorthy AV dan Zimmerman SW. 1978. Human Leukocyte Response to an Endurance Race. European Journal of Applied Physiology. 38: 271-276 
Nieman DC, Berg LS, Simpson-Westerberg M, Arabatzis K, et al . 1994. Effects of long-endurance on immune system parameters and Lymphocite Function in Experienced Marathoners. International of Journal of Sport Medicine, 10; 317-323

Norin AJ. 1989. Introduction to Immunobiologic. Concept. In (Miller AH, eds). Depressive Disorders and Immunity. Washington: American Psychiatric Press Inc

Kapit W, Macey RI, Meisami E. 1987. The Physiology Coloring Book. New York: Harper Collins Publishers.

Kumae T. 1987. Change in Serum Immunoglobulin Levels and Neutropilic Phagocytosis After Exercise. J Phys. Fitness sport Med 36:61-71

Peakman M dan Vergoni D. 1997. Basic and Clinical Immunologi. London. Churchill Livingstone

Setyawan S.1995. Pengaruh Latihan Fisik Aerobik dan Anaerobik terhadap Pola Respon Ketahanan Tubuh. Desertasi. Universitas Airlangga. Surabaya

Surkina LD dan Kozlovskoya LD. 1980. Blood Leucocythocis In Sportmen During Adaptation To Exercise. Lab Delo

MEDIKORA Vol. IV, No 1, April 2008: 47-65 